\title{
Response of Blue-winged Teal to Range Management on Waterfowl Production Areas in Southeastern South Dakota
}

\author{
PATRICK H. KAISER, STEPHEN S. BERLINGER, AND LEIGH H. FREDRICKSON
}

\section{Abstract}

The blue-winged teal (Anas discors) was the predominant upland-nesting waterfowl species in Waterfowl Production Areas (WPA's) in southeastern South Dakota. In native plant communities, factors that resulted in high nest density and success were excellent range condition (high proportion of climax vegetational and matted residual vegetation. In tame plant communities, smooth bromegrass (Bromus inermis) cover in which residual vegetation formed a matted mulch had high nest densities and nest success.

Many prime wetland areas that have been acquired in the prairie pothole region of the United States by the Fish and Wildlife Service are known as Waterfowl Production Areas and are managed as breeding habitat for waterfowl. Habitat conditions for nesting waterfowl are improved by the maintenance of certain vegetative characteristics of native and tame plant communities and by controlling the state of plant succession.

Conflicting opinions on proper management of grassland nesting cover for individual waterfowl species probably results from differences in habitats at different geographical locations and the proportion of different duck species on a study site. Nesting habitat in Iowa that had Kentucky bluegrass (Poa pratensis) as the dominant cover type and that was grazed lightly to moderately was more productive of blue-winged teal than was ungrazed habitat. Overgrazing was detrimental to teal production (Bennett 1938; Glover 1956; Burgess et al. 1965). Where the surface-feeding duck population included nearly equal proportions of mallards, gadwalls, pintails, and bluewinged teal in North Dakota, overall duck production was reduced considerably by grazing (Kirsh 1969). The potential production of upland nesting waterfowl will increase as our understanding of the relationships between plant and animal communities increases. Our study was designed to determine plant community types and vegetational characteristics present on the WPA's that provide habitat for upland-nesting waterfowl. Field work was conducted in spring and summer of 1974, while the senior author was a student employee at the Lake Andes National Wildlife Refuge, Lake Andes, South Dakota.

Authors are graduate assistant, Gaylord Memorial Laboratory, School of Forestry, Fisheries, and Wildlife, University of Missouri-Columbia, Puxico; refuge manager, Lake Andes National Wildlife Refuge, Lake Andes, South Dakota; and Director, Gaylord Memorial Laboratory, School of Forestry, Fisheries, and Wildlife, University of Missouri-Columbia, Puxico, Mo. Kaiser's present address is Wisconsin Department of Natural Resources. Poynette, Wisc.

Financial support for the research project was provided by the U.S. Fish and Wildlife Service through the Lake Andes National Wildlife Refuge. by the Missouri Cooperative Wildlite Research Unit. and by the Gaylord Memorial Laboratory. Authors thank the Lake Andes Wetland Management District personnel for providing material support (vehicles and cable-chain drag) and field assistance during nest-searching operations. They also thank Hugh E. Cosby, range ecologist, U.S. Fish and Wildlife Service, for his technical assistance throughout the study.

Manuscript received June 24, 1978.

\section{Study Area and Methods}

We studied 29 WPA's, in the prairie pothole region of southeastern South Dakota, that were acquired between 1963-1973. Twenty-two were in the Lake Andes Wetland Management District and 7 were in the Madison Wetland Management District. All were located in three vegetative zones recognized by Johnson and Nichols (1970) in eastern South Dakota: Zone 1-original tall grass prairie, Zone 2-tall-mixed grass transition area, and Zone 3-mixed grass prairie (Fig. 1).

In general, annual precipitation decreases from east to west and is 56 $\mathrm{cm}$ in the tall prairie, $51 \mathrm{~cm}$ in tall-mixed grass transition area, and 43 $\mathrm{cm}$ in the mixed grass praire. Precipitation was below normal in eastern South Dakota during January-July 1975 by $6.6 \mathrm{~cm}$ in the northern half of the study area and $14.7 \mathrm{~cm}$ in the southern half.

The study WPA's were selected to provide a representative sample of the upland plant communities. The presence of Type IV or Type $V$ wetland semipermanent-to-permanent water conditions (Stewart and Kantrud 1971) was a requirement for site selection.

Upland plant communities were classified as: (1) native prairie or (2) tame grass or legume seedings (seedings by mechanical techniques). Approximately 450 ha of native plant communities and 515 ha of seeded plant communities were selected for nest searching. Some of the tame grass and legume seedings were present at the time of acquisition and others were planted later, mainly during the period 1970-73. All tame plant communities were left idle after acquisition or planting.

In general, the tracts of native prairie have degenerated because of poor management before acquisition or because they were left in a resting state for as many as 8 years after acquisition. Consequently, periodic manipulation was necessary. Burning is recognized as an effective management tool to maintain prairie grasslands, but the

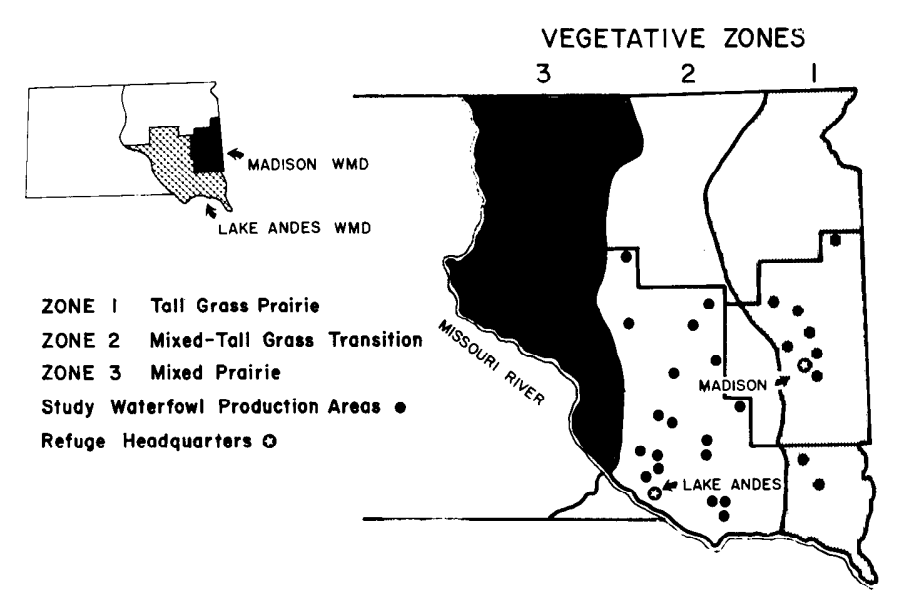

Fig. 1. Vegetational zones within the Lake Andes and Madison Wetland Management Districts in southeastern South Dakota and the Waterfowl Production Areas (WPA's) of the study area. 
Table 1. Total ducks nests, nest success, and nest density in native vs. tame plant communities in southeastern South Dakota, 1974.

\begin{tabular}{|c|c|c|c|c|c|c|}
\hline \multirow[b]{2}{*}{ Species } & \multicolumn{4}{|c|}{ All nests } & \multirow{2}{*}{$\frac{\text { Native }^{3}}{\begin{array}{c}\text { Number } \\
\text { nests }\end{array}}$} & \multirow{2}{*}{$\frac{\text { Tame }}{\begin{array}{c}\text { Number } \\
\text { nests }\end{array}}$} \\
\hline & Number & $\begin{array}{c}\text { Nonactive } \\
\text { nests }^{1}\end{array}$ & $\begin{array}{c}\text { Percent } \\
\text { composition }^{2}\end{array}$ & $\begin{array}{c}\text { Number } \\
\text { successful }\end{array}$ & & \\
\hline Blue-winged teal & 210 & 13 & 79.8 & $95(43)^{4}$ & $104(49)^{4}$ & $106(36)^{4}$ \\
\hline Mallard & 23 & 3 & 8.7 & $8(37)$ & $4(67)$ & $19(30)$ \\
\hline Gadwall & 23 & 2 & 8.7 & $13(57)$ & $3(100)$ & $20(51)$ \\
\hline Pintail & 4 & 0 & 1.6 & $2(42)$ & $3(100)$ & $3(22)$ \\
\hline Shoveler & 3 & 0 & 1.2 & $0(0)$ & $1(44)$ & $0(0)$ \\
\hline Total & 263 & 18 & 100 & $118(43)$ & $115(50)$ & $148(36)$ \\
\hline Nest density & & & & & $25.6 / \mathrm{km}^{2}$ & $28.7 / \mathrm{km}^{2}$ \\
\hline
\end{tabular}

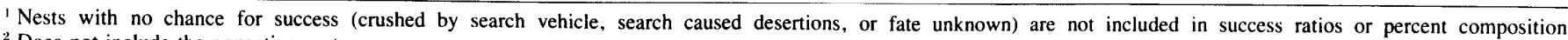
2 Does not include the nonactive nests.

${ }^{3}$ Native $=47 \%$ of area searched; Tame $=53 \%$ of area searched

${ }^{2}$ Nest success calculated by Mayfield (1961) method.

combination of limited manpower and wide distribution of WPA's reduced the applicability of this technique in this area where many units were no larger than 32 ha. To reduce the thick mat of residual vegetation, some native tracts were hayed or grazed in 1973.

Before the arrival of the breeding waterfowl in spring, we determined range site (Dodds and Galt 1973), range condition (Dyksterhuis 1949), and mulch condition for native plant communities, and plant species composition and mulch condition for the tame plant communities. Mulch condition, meaning the stature of the residual vegetation, was determined by visual observation and described as being either upright (standing) or matted (fallen over).

Nest searching was conducted between 0800 and 1700 hours with the use of a cable-chain drag (Higgins et al. 1969). Two nest searches were conducted on each WPA between May 7 and Junc 27, with an approximate 25-day interval between the two. Nests were examined to determine waterfowl species, stage of incubation (Weller 1956), vegetation height, nest concealment, and plant species composition. Cover density height was determined by the method of Higgins and Kantrud (1973). Nests were revisited after the estimated date of hatch to determine success. Calculations for nest success included differences in exposure time of individual nests as recommended by Mayfield (1961). Consequently, nest success is not represented by a simple fraction conversion to a percentage basis.

\section{Results and Discussion}

\section{Native and Tame Plant Communities Combined}

A total of 263 waterfowl nests were located in the study area. Blue-winged teal accounted for $210(79.8 \%)$ of the nests (Table 1). This proportion was considerably higher than the proportion $(38 \%)$ of blue-winged teal found nesting in north-central South Dakota during 1971-73 by Duebbert and Lokemoen (1976). During 1974, blue-winged teal accounted for $59 \%$ of the pairs of surface-feeding ducks east of the Missouri River in an area that was comparable with ours (Brewster et al. 1976).

Nest success for blue-winged teal as well as for all waterfowl species was $43 \%$ (Table 1). This is considerably lower than the $70 \%$ suggested as the objective for nest success on managed areas (Kalmbach 1939).

\section{Native Plant Community vs. Tame Plant Community}

The native plant community made up 451 ha $(47 \%)$ and the tame plant community 515 ha $(53 \%)$ of the 966 ha of upland habitat searched on the study area. Nests of all waterfowl combined were more numerous in the tame plant community, which had $56 \%$ of the nests or 28.7 nests $/ \mathrm{km}^{2}$, compared to the native plant community, which had $44 \%$ of the nests or 25.6 nests $/ \mathrm{km}^{2}$ (Table $\mathrm{l}$ ).

Nesting densities of blue-winged teal were slightly greater (23.1 nests $/ \mathrm{km}^{2}$ ) in native plant communities than in tame plant communities (20.6 nests $\left./ \mathrm{km}^{2}\right)$. With the exception of teals and shovelers (Anas clypeata), waterfowl preferred the tame plant community by about a 3 to 1 ratio (Table 1 ).

Nest success for all waterfowl was considerably higher in the native plant community $(50 \%)$ than in the tame plant community $(36 \%)$. Blue-winged teal nest success was $49 \%$ in the native plant community and $36 \%$ in the tame plant community (Table 1).

\section{Native Plant Community \\ Range Condition}

Range condition reflects the health of the native plant community and is defined as the percentage. of vegetation present that is climax vegetation for the site (Dyksterhuis 1958). Waterfowl nest density was highest $\left(26.4 \mathrm{nests} / \mathrm{km}^{2}\right)$ on rangeland in excellent condition. As range condition deteriorated, nest density decreased accordingly (Table 2 ). Nest success was highest in native plant communities in fair $(67 \%)$ and excellent $(61 \%)$ range condition.

Kentucky bluegrass invasion into the native plant community was the most important factor causing the deterioration of range condition below the "excellent" category. Improper timing of grazing, haying, or burning may result in range deterioration. Overgrazing as well as excessive rest periods may favor bluegrass invasion into native plant communities (Cosby and Berlinger 1973).

\section{Mulch Condition}

The residual plant material from the vegetative growth of the previous year or years often is used for duck nests. Nest density was higher on sites with the matted mulch $\left(32.2\right.$ nests $\left./ \mathrm{km}^{2}\right)$ than on sites with the upright mulch $\left(24.0\right.$ nests $\left./ \mathrm{km}^{2}\right)$. Of the waterfowl nests in matted mulch, $66 \%$ were successful as compared with $45 \%$ in vegetation with upright mulch (Table 3 ).

Matted mulch is generally associated with long rest periods and/or natural forces such as prolonged periods of heavy snowpack. As excessive mulch accumulates, the range condition deteriorates because native grass growth is depressed. The stature of the mulch (matted vs. upright) appears to be more

Table 2. Duck nest density and nest success in relation to the range condition of the native plant communities, 1974.

\begin{tabular}{lccc}
\hline Range condition & $\begin{array}{c}\text { Nests } \\
\text { found }\end{array}$ & $\begin{array}{c}\text { Density } \\
\text { (nests } / \mathrm{km}^{2} \text { ) }\end{array}$ & $\begin{array}{c}\text { Percent } \\
\text { success }\end{array}$ \\
\hline Excellent & 19 & 26.4 & 61 \\
Good & 57 & 25.4 & 38 \\
Fair & 25 & 24.0 & 67 \\
Poor & 11 & 22.4 & 30 \\
\hline
\end{tabular}


Table 3. Duck nest density and nest success in matted and upright mulch condition within native plant community, 1974.

\begin{tabular}{lcccc}
\hline Mulch condition & $\begin{array}{c}\text { Hectares } \\
\text { searched }\end{array}$ & $\begin{array}{c}\text { Density } \\
\left.\text { (nests } / \mathbf{k m}^{2}\right)\end{array}$ & $\begin{array}{c}\text { Nests } \\
\text { found }\end{array}$ & $\begin{array}{c}\text { Percent } \\
\text { success }\end{array}$ \\
\hline Matted & 87.5 & 32.2 & 25 & 66 \\
Upright & 363.2 & 24.0 & 87 & 45 \\
\hline
\end{tabular}

important in relation to duck nesting rather than the amount of mulch material that accumulates from year to year. Proper maintenance of native plant communities requires some type of periodic manipulation to attain or maintain excellent range condition.

\section{Tame Plant Community Plant Groups}

The tame plant community was subdivided into six plant groups consisting of alfalfa (Medicago sativa); alfalfa-tame grass mixtures, Kentucky bluegrass, smoothbromegrass, or intermediate wheatgrass (Agropyron intermedium); sweet clover mixture (Melilotus sp.), smooth bromegrass, intermediate wheatgrass; and forbs or annual grasses (Table 4). Nest density was highest ( 185.7 nests $/ \mathrm{km}^{2}$ ) in the forbs and annual grasses, however, this figure is misleading because there was only one nest in the 6.7 ha of that plant group. The other 12 nests within this category were in small stands of forbs or annual grasses within tracts of vegetation represented by the other five plant groups.

The nest density of 54 nests $/ \mathrm{km}^{2}$ for smooth bromegrass was higher (Chi-square, $P \leq 0.05$ ) than the densities in the other major plant groups. Smooth bromegrass accounted for $24 \%$ of the 515 ha in tame plant communities, but contained $46 \%$ of all nests and $49 \%$ of the blue-winged teal nests, thus re-emphasizing the preference of blue-winged teal for smooth bromegrass as nesting sites (Table 4)

Low waterfowl nest densities occurred in homogeneous bromegrass stands in North Dakota (Salyer 1962, Schrank 1966), but bromegrass in small blocks was used extensively (Schrank 1966). The largest block of bromegrass in our study area, 34.4 ha, containcd 8 duck nests. Other homogeneous bromegrass stands of $12.6,8.9$, and 6.9 ha contained 9,12 , and 6 duck nests respectively.

Blue-winged teal accounted for $72 \%$ of the waterfowl nests in the tame plant communities. The low nest densities in alfalfa ( 10.1 nests $\left./ \mathrm{km}^{2}\right)$ and sweet clover mixture $\left(12.7 \mathrm{nests} / \mathrm{km}^{2}\right)$ in our study undoubtedly are related to the predominance of nesting by blue-winged teal and their preference for grassland communities. High duck nest densities have been found in homogeneous stands of alfalfa or sweet clover mixtures (Salyer 1962; Duebbert and Kantrud 1974) when the nesting population consisted primarily of mallards (Anas platyrhynchos), gadwalls (Anas strepera), and pintails (Anas acuta).

\section{Mulch Condition}

Within the tame plant communities duck nest density was 28.4 nests $/ \mathrm{km}^{2}$ in the matted mulch and 28.8 nests $/ \mathrm{km}^{2}$ in the upright mulch (Table 4). Nest densities were similar for both matted and upright mulch within each plant group where both mulch conditions were available for sampling (alfalfa, alfalfatame grass mixture, smooth bromegrass, and intermediate wheatgrass).

Waterfowl nest success for the overall tame plant community was higher where the mulch was matted than where it was upright (49 versus $35 \%$, Table 4 ). The higher nest success in the matted mulch was noted for the native plant community also. Nest success within the various plant groups in both the matted and upright mulch was variable. The high nest success in the alfalfa-tame grass mixture (73\%) and smooth bromegrass (67\%) with matted mulch suggests that such a combination may help deter predation on waterfowl nests in tame plant communities.

\section{Management Recommendations}

Habitat acquired as WPA's has the potential to produce substantial numbers of waterfowl. Because many WPA's are poor quality upland nesting habitat at the time of acquisition, nesting habitat improvement should receive attention from managers. Manipulation to improve upland cover should be based on the composition of local waterfowl populations and on nesting requirements for the most common species.

Our results as well as those of three Iowa studies (Bennett 1938; Glover 1956; and Burgess et al. 1965) suggest that bluewinged teal production increased following grazing. Both nest density and nest success for blue-winged teal in South Dakota were higher for native plant communities in excellent range condition. Management can attain these conditions by proper use of burning, grazing, resting, and haying.

Native plant communities with matted mulch had the highest nest success and nest density. In our study area, matted mulch resulted after rest periods from 1 to 3 years, but longer rest periods tended to degrade the range condition. The appropriate rest period for each native plant community should be based on range site, climate, and weather.

Smooth bromegrass had the highest nest density of all tame plant groups. More nests were successful in the tame communities when mulch was matted rather than upright. The best manipulations for tame grass groups to enhance waterfowl production are unknown. However, in our study area tame plant groups had been rested for at least 4 years and as long as 9 years. Apparently, high populations of nesting blue-winged teal can be

Table 4. Nest density and nest success in the matted and upright mulch conditions and percent nests in the tame plant groups, 1974.

\begin{tabular}{|c|c|c|c|c|c|c|c|}
\hline \multirow[b]{2}{*}{ Plant community } & \multicolumn{3}{|c|}{ All nests } & \multicolumn{2}{|c|}{ Matted mulch } & \multicolumn{2}{|c|}{ upright mulch } \\
\hline & $\begin{array}{c}\text { Density } \\
\left.\text { (nests } / \mathbf{k m}^{2}\right)\end{array}$ & $\begin{array}{c}\text { Percent } \\
\text { area }\end{array}$ & $\begin{array}{c}\text { Percent } \\
\text { nests }\end{array}$ & $\begin{array}{c}\text { Density } \\
\left(\text { nests } / \mathrm{km}^{2} \text { ) }\right.\end{array}$ & $\begin{array}{l}\text { Percent } \\
\text { success }\end{array}$ & $\begin{array}{c}\text { Density } \\
\left(\text { nests } / \mathrm{km}^{2} \text { ) }\right.\end{array}$ & $\begin{array}{l}\text { Percent } \\
\text { success }\end{array}$ \\
\hline Smooth bromegrass & 54.0 & 24 & $46(68)^{1}$ & $45.4(10)^{1}$ & 67 & $55.8(58)^{1}$ & 39 \\
\hline Alfalfa mixture & 28.2 & 20 & $20(29)$ & $21.6(8)$ & 73 & $31.8(21)$ & 32 \\
\hline Intermediate wheatgrass & 25.6 & 8 & $7(10)$ & $33.3(1)$ & 9 & $25.0(9)$ & 64 \\
\hline Alfalfa & 10.1 & 27 & $10(15)$ & $12.5(5)$ & 0 & $10.1(10)$ & 48 \\
\hline Sweet clover mixture & 12.7 & 20 & $9(13)$ & ( 1$)$ & 100 & $11.8(12)$ & 9 \\
\hline Forbs and annual grasses & 185.7 & 1 & $9(13)$ & $(4)$ & 13 & $128.6(9)$ & 14 \\
\hline Total & & & & $28.4(29)$ & 49 & $28.8(119)$ & 35 \\
\hline
\end{tabular}

Number of nests. 
maintained on WPA's during wet cycles if native plant communities are in excellent range condition or if smooth bromegrass stands are established on lands previously under cultivation.

\section{Conclusion}

The use of range condition and range site to assess the successional status of native prairie in relation to climax provides a means of assessing conditions at the plant community level rather than dealing with specific plant species or given vegetation densities or heights. Our data suggest that native prairie can be made most attractive to nesting blue-winged teal by grazing with the intent to reach a specific range condition. Although grazing and haying are used on the WPA's in South Dakota, burning is a viable alternative. A similar understanding of tame plant groups in relation to soil types and plant species requirements for establishment and maintenance is needed for achieving optimum management for upland nesting habitat.

\section{Literature Cited}

Bennett, L.J. 1938. The Blue-winged Teal, Its Ecology and Management. Collegiate Press, Inc., Ames, Iowa. 144 p.

Brewster, W.G., J.M. Gates, and L.D. Flake. 1976. Breeding waterfowl populations and their distribution in South Dakota. J. Wildl. Manage. 40:50-59.

Burgess, H.H., H.H. Prince, and D.L. Trauger. 1965. Blue-winged teal nesting success as related to land use. J. Wildl. Manage. 29:89-95.

Cosby, H., and S. Berlinger. 1973. Altering influences and certain management effects on range ecosystems. Unpubl. Rep. Lake Andes NWR files. $32 \mathrm{p}$.
Dodds, D.L, and H.D. Galt. 1973. Range site identification. North Dakota State Univ. Coop. Ext. Serv. 6 p.

Duebbert, H.F. 1969. High nest density and hatching success of ducks on South Dakota CAP land. Trans. N. Amer. Wildl. Natur. Resour. Conf. 34:218-228.

Duebbert, H.F., and H.A. Kantrud. 1974. Upland duck nesting related to land use and predator reduction. J. Wildl. Manage. 38:257-265.

Dubbert, H.F., and J.T. Lokemoen. 1976. Duck nesting in fields of undisturbed grass-legume cover. J. Wildl. Manage. 40:39-49.

Dyksterhuis, E.J. 1949. Condition and management of rangeland based on quantitative ecology. J. Range Manage. 2:104-115.

Dyksterhuis, E.J. 1958. Range conservation as based on sites and condition classes. J. Soil Water Conserv. 13:151-155.

Glover, F.A. 1956. Nesting and production of blue-winged teal (Anas discors Linnaeus) in northwest lowa. J. Wildl. Manage. 20;28-46.

Higgins, K.F., and H.A. Kantrud. 1973. Increasing bird nest success on cultivated lands. North Dakota Outdoors. 35:18-21.

Higgins, K.F., L.M. Kirsh, and I.J. Ball, Jr. 1969. A cable-chain device for locating duck nests. J. Wildl. Manage. 33:1009-1011.

Johnson, J.R., and J.T. Nicholds. 1970. Plants of South Dakota grasslands. South Dakota State Univ. Agr. Exp. Sta. Bull. 566. 163 p.

Kalmbach, E.R. 1939. Nesting success: its significance in waterfowl production. Trans. N. Amer. Wildl. Conf. 4:591-604.

Mayfield, H. 1961. Nesting success calculated from exposure. Wilson Bull. 73:255-261.

Salyer, J.W. 1962. Effects of drought and land use on prairie nesting ducks. Trans. N. Amer. Wildl. Natur. Resour. Conf. 27:69-79.

Schranck, B.W. 1966. Waterfowl nest densities and nest predation. MA Thesis, Univ. Missouri-Columbia. 104 p.

Stewart, R.E., and H.A. Kantrud. 1971. Classification of natural ponds and lakes in the glaciated prairie region. U.S. Fish Wildl. Serv. Resour. Pub. 92. $57 \mathrm{p}$.

Weller, M.W. 1956. A simple field candler for waterfowl eggs. J. Wildl. Manage. 20:111-113.

\section{3rd Annual Meeting Society for Range Management February 11-14, 1980 San Diego, California}

For additional information and reservation forms (after October 20, 1979), contact the Office of the Executive Secretary, Society for Range Management, 2760 West Fifth Avenue, Denver Colorado 80204 • (303) 571-0174. 